\title{
Anatomical and histochemical study of Sechium edule (Jacq.) Sw.
}

Francilainy Karina de Andrade Silva ${ }^{1}$, Cledson dos Santos Magalhães ${ }^{1}$, Rafaela Damasceno Sá1, Flávia Carolina Lins da Silva ${ }^{2} \&$ Karina Perrelli Randau ${ }^{1}$

1 Departamento de Ciências Farmacêuticas, Universidade Federal de Pernambuco, 50740-321, Recife, Pernambuco, Brazil.

2 Departamento de Biologia, Universidade Federal Rural de Pernambuco, 52171-900, Recife, Pernambuco, Brazil.

\author{
Correspondence \\ K.P. Randau \\ E-mail: krandau@hotmail.com \\ Received: 2 April 2020 \\ Accepted: 31 August 2020 \\ Published on-line: 18 December 2020
}

\section{Resumen}

Estudio anatómico e histoquímico de Sechium edule (Jacq.) Sw.

Sechium edule (Jacq.) Sw. tiene un papel importante nutricional y terapéuticamente en la medicina popular, especialmente utilizado como agente hipotensor. Para ampliar la información farmacológica sobre esta especie, este trabajo tiene como objetivo el estudio histoanatómico de sus hojas. Se prepararon muestras con secciones transversales y paradérmicas de la hoja para el estudio microscópico. Para el análisis histoquímico, se utilizaron reactivos específicos para los metabolitos objetivo. A través del análisis realizado se identificaron estructuras anatómicas para la correcta identificación de la especie estudiada. La histoquímica mostró la presencia de alcaloides, triterpenos y esteroides, compuestos lipofílicos y lignina. Esta información sobre la localización de los compuestos no tiene precedentes. Así, el trabajo amplía el conocimiento sobre la especie y la familia Cucurbitaceae.

Palabras clave: Chuchu, Chayote, Cucurbitaceae, Farmacobotánica, Microscopía.

\begin{abstract}
Sechium edule (Jacq.) Sw. plays an important role as for its nutritional and therapeutical use in folk medicine, being especially used as a hypotensive agent. In order to expand the pharmacobotanical information on this species, this work aims to perform the histoanatomical study of its leaves. Samples containing cross-section and paradermic sections of the leaf were prepared for microscopic study. For the histochemical analysis, specific reagents were used, according to the targeted metabolites. Through the performed analysis, it was possible to identify the anatomical structures that confer the correct identification of the studied species. The histochemistry showed the presence of alkaloids, triterpenes and steroids, lipophilic compounds and lignin. This information on the localisation of the compounds is unprecedented. Thus, the work expands the knowledge about the species and the family Cucurbitaceae.
\end{abstract}

Key words: Chuchu, Chayote, Cucurbitaceae, Pharmacobotany, Microscopy. 


\section{Introduction}

The Cucurbitaceae family is among the plants families of great importance in the world's economy, due to species used in food and in the pharmaceutical industry (Rajasree et al. 2016, Ajuru \& Nmom 2017). According to Christenhusz \& Byng (2016), the Cucurbitaceae family has 95 genera and 965 species, widely distributed among the tropics and subtropics, with few species occurring in temperate regions. In Brazil, cucurbits represent an important family, with 160 species distributed in 28 genera (Gomes-Klein et al. 2015).

Among the genera present in Brazil, the genus Sechium P. Browne was regarded as monospecific, containing only Sechium edule (Jacq.) Sw. (Saade 1996). However, since the 1970s, new findings have been discussed and the authors consider that the genus Sechium comprises about six to eight species (Madison 2017). The species $S$. edule, popularly known as chuchu or chayote, originates in Central America, where it was initially planted as a vegetable by the Aztecs. $\mathrm{Cu}$ rrently it is cultivated in tropical and subtropical countries because its fruits are sources of vitamins, minerals, fibers and starch (Mishra \& Das 2015). In addition to fruits, roots, stems and leaves can also be eaten (Madison 2017) in different forms.

The medicinal use of $S$. edule has been cited in ethnobotanical surveys. In Brazil, most used parts for medicinal purposes are leaves and fruits, in the form of infusion or decoction. The main indication of leaves and fruits is as an hypotensive agent (Medeiros et al. 2004, Vendruscolo \& Mentz 2006, Agra et al. 2008, Pereira et al. 2012, Santos et al. 2012, Rodrigues \& Andrade 2014, Messias et al. 2015), but they are also used as sedatives (Messias et al. 2015, Souza et al. 2016). The leaves can also be used to treat urinary infection (Oliveira et al. 2010).

Vieira et al. (2019) reported that $S$. edule has a diversity of bioactive compounds such as alkaloids, saponins, flavonoids, triterpenes and steroids. In addition, they also showed that the species has several biological activities. Among them, the anti-cardiovascular, anti-diabetic, antiobesity, antioxidant, anti-inflammatory, anti-ulcer, anticancer, anti-mutagenic, anti-microbial, antiepileptic and hepatoprotective properties are the most cited.

Despite finding studies on the chemical com- pounds of $S$. edule in the literature, no information was found on the exact localisation of these compounds. In addition, anatomical studies seek for potential characters with taxonomic value, contributing to enrich knowledge about the genus Sechium and the family Cucurbitaceae. Given the medicinal importance of $S$. edule, studies involving an accurate identification of the plant are necessary to establish the quality parameters necessary for its use. Thus, this study aimed to describe anatomically the leaf of $S$. edule, as its most important vegetal product, as well as identifying the sites of the synthesis or accumulation of metabolites in the leaf lamina.

\section{Materials and methods}

\section{Plant material}

Plant samples were collected at Engenho Serra Grande, Rural Zone of Vitória de Santo Antão, State of Pernambuco, Brazil. A voucher specimen $\left(n^{\circ}\right.$ 93.027) was deposited in the Herbarium Dárdano de Andrade Lima, from the Instituto Agronômico de Pernambuco. The leaves used in this study were collected between the third and fifth nodes.

\section{Anatomy}

For anatomical characterization, the material was fixed in FAA50 (formaldehyde, acetic acid and ethyl alcohol 50\%, 1: 1: $18 \mathrm{v} / \mathrm{v}$ ) (Johansen 1940). Cross-sections of petiole and leaf lamina were obtained through the use of razor blades and petiole included in medulla (Cecropia sp.) as a support material. For the leaf lamina, paradermic sections were also performed, on the adaxial and abaxial faces. Subsequently, sections were exposed to a solution of sodium hypochlorite $50 \%$ for clarification (Kraus \& Arduin 1997). After washing in distilled water, the cross-sections were stained according to the technique described by Bukatsch (1972), with safranin and Astra blue. Paradermic sections were stained with methylene blue (Krauter 1985). Afterwards, all sections were assembled on semipermanent slides, following usual procedures described by (Johansen 1940, Sass 1951). The analysis of microscopic slides was performed using an optical and microscope (Leica DM750M), equipped with a digital camera (Leica ICC50W), and the processed images were obtained through software (Leica LAS EZ). 


\section{Histochemistry}

Histochemical tests were performed on cross-sections of fresh leaf lamina, obtained by freehand technique, using razor blades and petiole included in medulla (Cecropia sp.) as support material. The following reagents were used to indicate the presence of metabolites: potassium dichromate (10\%) for phenolic compounds (Johansen 1940), Dragendorff's reagent for alkaloids (Yoder \& Mahlberg 1976), antimony trichloride for triterpenes and steroids (Mace et al. 1974), hydrochloric vanillin for tannins (Mace \& Howell 1974), Sudan III for lipophilic compounds (Sass 1951), phloroglucinol for lignin (Johansen 1940) and Lugol for starch (Johansen 1940). Controls were studied in parallel with the histochemical slides. The analysis of slides was performed using an optical microscope (Leica DM750M), equipped with a digital camera (Leica ICC50W), and the pro- cessed images were obtained through software (Leica LAS EZ).

\section{Results}

\section{Anatomy}

The petiole of $S$. edule, in cross-section, has an angular shape, with a larger indentation on the adaxial face (Figs. 1A and 1B). The uniseriate epidermis (Fig. 1C) shows glandular (Fig. 1C) and non-glandular trichomes (Fig. 1D). The glandular trichomes have a uniseriate and multicellular body and four-cell head (Fig. 1C). Non-glandular trichomes are uniseriate and multicellular (Fig. 1D). Underneath the epidermis, there are two to six layers of discontinuous angular collenchyma (Figs.1A and 1B). Thirteen bicollateral vascular bundles are arranged in a circular shape around the section outline (Figs. 1A and 1B).
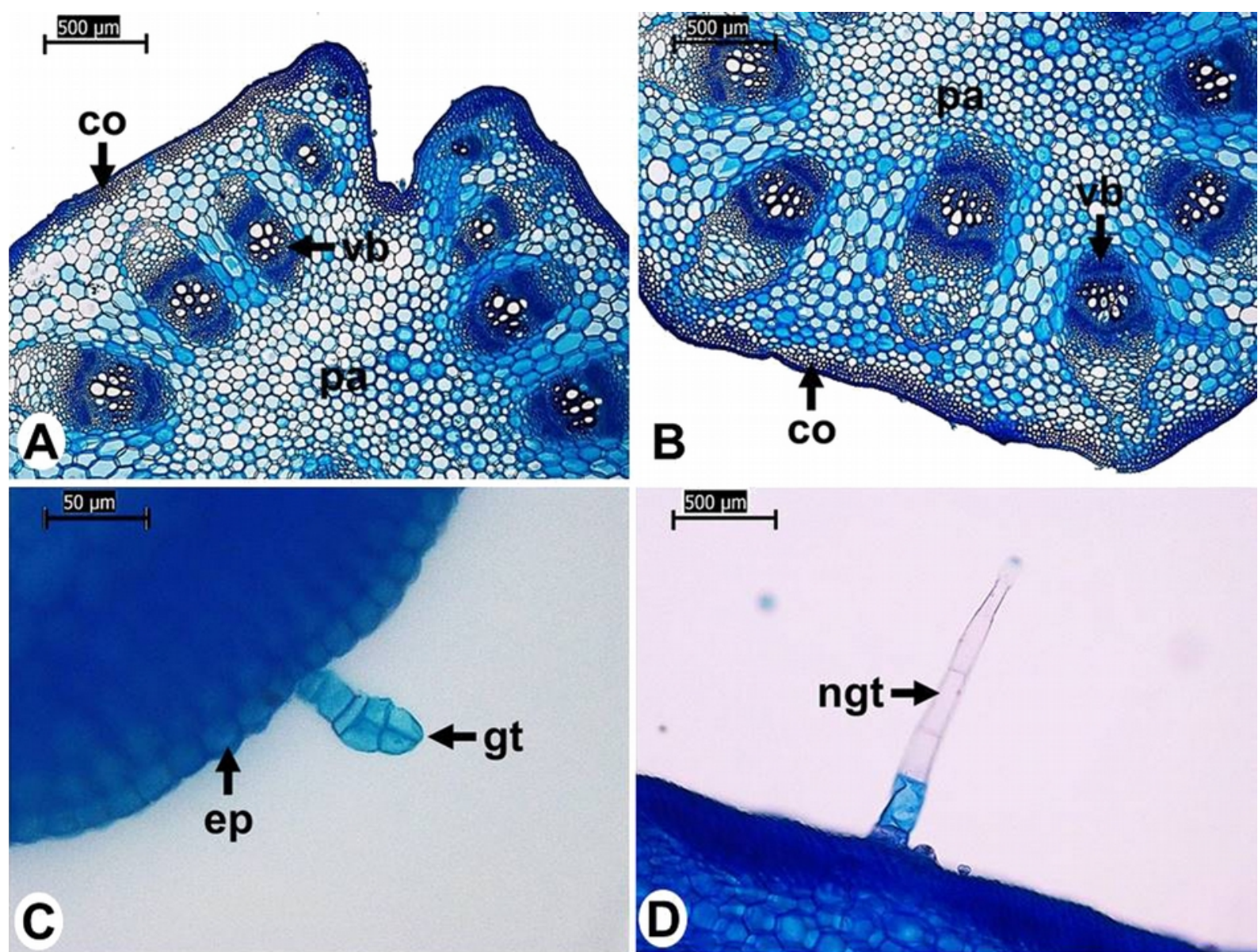

Figura 1. Secciones transversales del pecíolo de Sechium edule (Jacq.) Sw. A: vista general de la cara adaxial, B: vista general de la cara abaxial, C: detalle del tricoma glandular, D: detalle del tricoma tector. co: angular colénquima, ep: epidermis, gt: tricoma glandular, ngt: tricoma tector, $p a$ : parénquima, $v b$ : haz vascular. Colorante: safranina y azul Astra. Microscopio óptico Leica DM750M.

Figure 1. Cross-sections of the petiole of Sechium edule (Jacq.) Sw. A: general view of the adaxial face, B: general view of the abaxial face, C: detail of glandular trichome, D: detail of non-glandular trichome. co: angular collenchyma, ep: epidermis, gt: glandular trichome, ngt: non-glandular trichome, $p a$ : parenchyma, $v b$ : vascular bundle. Stain: safranin and Astra blue. Optical microscope Leica DM750M. 

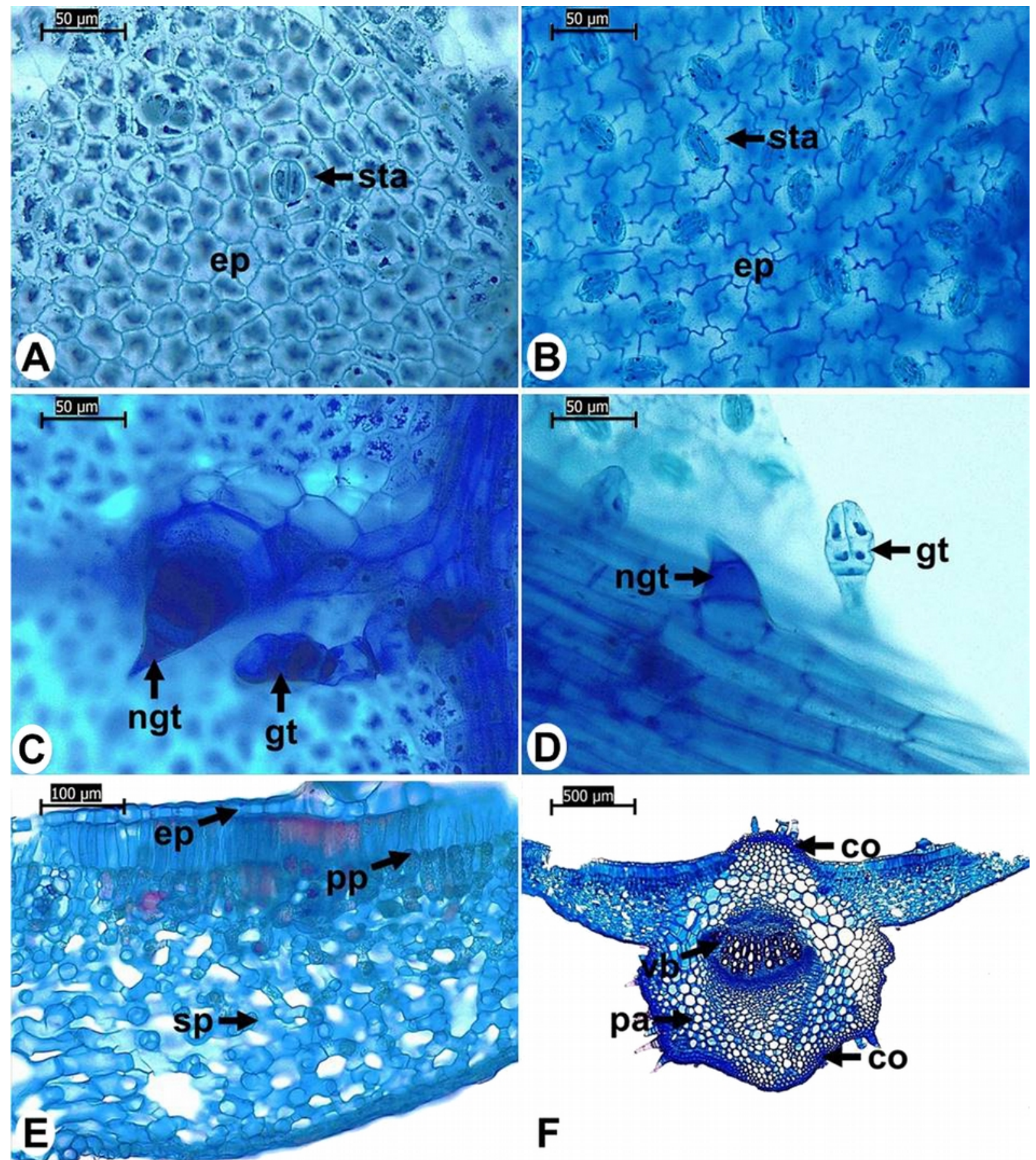

Figura 2. Vista frontal y secciones transversales de la lámina foliar de Sechium edule (Jacq.) Sw. A, C: superfície adaxial, B, D: superfície abaxial, E: mesofilo, F: nervadura central. co: angular colénquima, ep: epidermis, gt: tricoma glandular, ngt: tricoma tector, $p a$ : parénquima, $p p$ : parénquima en empalizada, $s p$ : parénquima esponjoso, $s t a$ : estoma, $v b$ : haz vascular. Colorante: azul de metileno (A y B), safranina y azul Astra (C, D, E y F). Microscopio óptico Leica DM750M.

Figure 2. Frontal view and cross-sections of the leaf blade of Sechium edule (Jacq.) Sw. A, C: adaxial face, B, D: abaxial face, E: mesophyll, F: midrib. $c o$ : angular collenchyma, ep: epidermis, gt: glandular trichome, ngt: non-glandular trichome, $p a$ : parenchyma, $p p$ : palisade parenchyma, $s p$ : spongy parenchyma, $s t a$ : stoma, $v b$ : vascular bundle. Stain: methylene blue (A and B), safranin and Astra blue (C, D, E and F). Stain: methylene blue (A and B), safranin and Astra blue (C, D, E and F). Optical microscope Leica DM750M.

In the adaxial face of paradermic leaf lamina section of $S$. edule, the epidermal cells show a slightly sinuous outline walls (Fig. 2A), while the abaxial face exhibits epidermal cells with strongly sinuous outline walls (Fig. 2B). Leaf lamina is amphiestomatic, with anomocytic stomata being more frequent on the abaxial face (Figure 2B). Glandular and non-glandular trichomes were observed on both faces (Figs. 2C and 2D). The glandular trichomes are similar to those found in the petiole. Non-glandular trichomes are uniseriate and multicellular, however, they differ from 


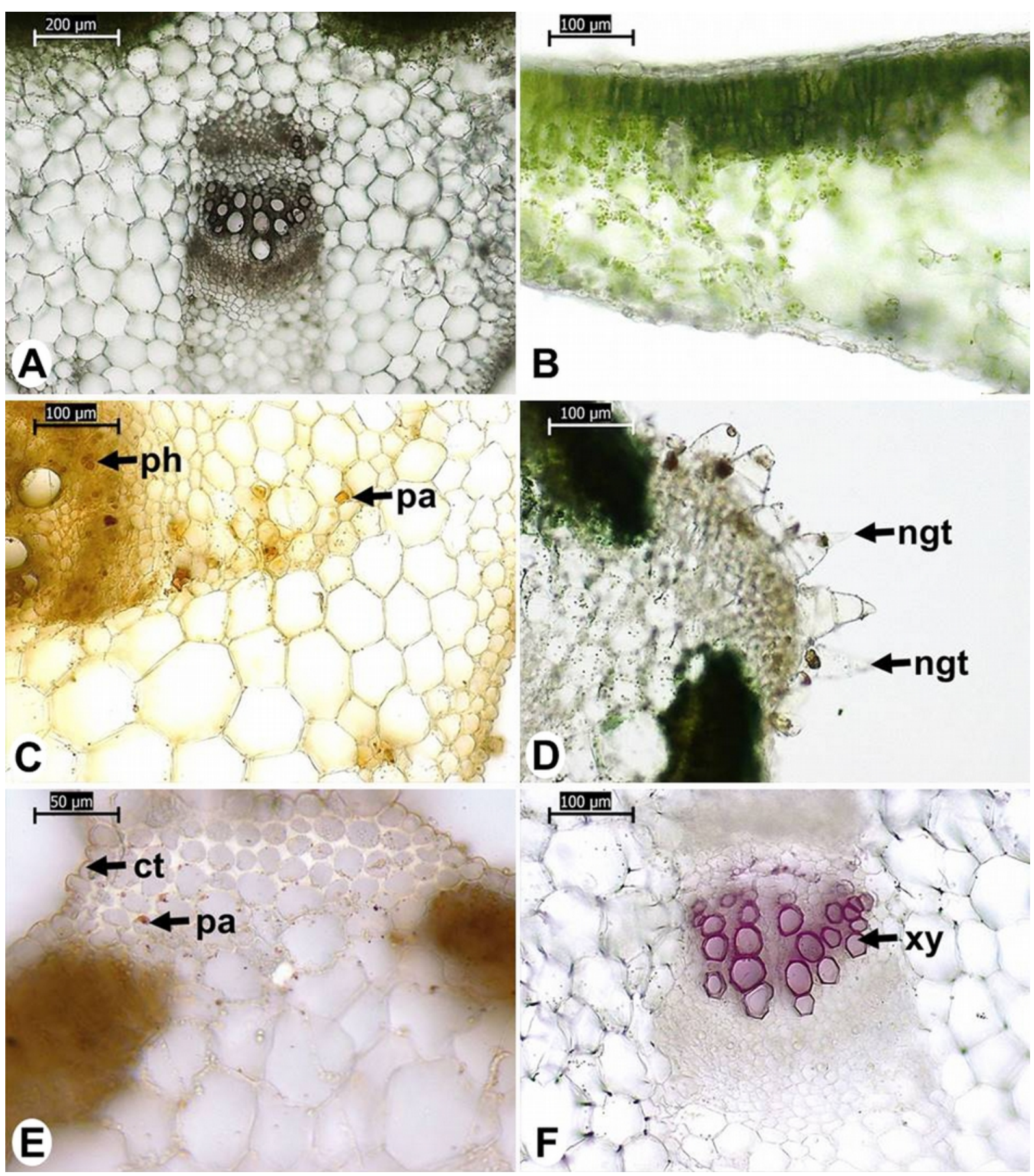

Figura 3. Histoquímica de la lámina foliar de Sechium edule (Jacq.) Sw. A, B: control, C: reactivo de Dragendorff, D: tricloruro de antimonio, E: Sudan III, F: floroglucinol. ct: cutícula, ngt: tricoma tector, pa: parénquima, $p h$ : floema, $x y$ : xilema. Microscopio óptico Leica DM750M.

Figure 3. Histochemistry of the leaf blade of Sechium edule (Jacq.) Sw. A, B: control, C: Dragendorff's reagent, D: antimony trichloride, E: Sudan III, F: phloroglucinol. ct: cuticle, ngt: non-glandular trichome, pa: parenchyma, ph: phloem, $x y$ : xylem. Optical microscope Leica DM750M

non-glandular trichomes found in the petiole because they have a conical shaped apical cell.

In cross-section, the epidermis of the leaf blade is uniseriate, covered by a thin layer of cutin, which represents the cuticle (Fig. 2E). The mesophyll is dorsiventral, with the palisade parenchyma showing one to three cell layers (Fig.
2E). It is observed that the closer to the central vein, there are more layers of cells. The midrib has a biconvex shape, with about two layers of discontinuous angular collenchyma on each side (Fig. 2F). In the central region of the central vein, a bicollateral vascular bundle can be noticed (Fig. 2F). 


\section{Histochemistry}

The figures $3 \mathrm{~A}$ and $3 \mathrm{~B}$ show the leaf blade without adding any reagent. Alkaloids were found in the parenchyma and phloem that are located near the central vein (Fig. 3C). Triterpenes and steroids were visualized in the base and body cells of the non-glandular trichomes (Fig. 3D). Lipophilic compounds were evidenced in the cuticle and parenchyma near the central vein (Fig. 3E) and lignin was observed in the xylem (Fig. 3F). Tests for phenolic compounds, tannins and starch were negative. The table 1 gathers the information observed through histochemistry.

\begin{tabular}{|c|c|c|}
\hline REAGENT & METABOLITE & SITE \\
\hline $\begin{array}{c}\text { Potassium } \\
\text { dichromate } 10 \%\end{array}$ & $\begin{array}{c}\text { phenolic } \\
\text { compounds }\end{array}$ & - \\
\hline Dragendorff & alkaloids & $\begin{array}{c}\text { parenchyma and } \\
\text { phloem }\end{array}$ \\
\hline $\begin{array}{l}\text { Antimony } \\
\text { trichloride }\end{array}$ & $\begin{array}{l}\text { triterpenes and } \\
\text { steroids }\end{array}$ & $\begin{array}{l}\text { base and body cells of } \\
\text { non-glandular } \\
\text { trichomes }\end{array}$ \\
\hline $\begin{array}{l}\text { Hydrochloric } \\
\text { vanillin }\end{array}$ & tannins & (2) \\
\hline Sudan III & $\begin{array}{l}\text { lipophilic } \\
\text { compounds }\end{array}$ & $\begin{array}{l}\text { cuticle and } \\
\text { parenchyma }\end{array}$ \\
\hline $\begin{array}{l}\text { Phloroglucinol } \\
\text { Lugol }\end{array}$ & $\begin{array}{l}\text { lignin } \\
\text { starch }\end{array}$ & xylem \\
\hline
\end{tabular}

Tabla 1. Sitios de síntesis y acumulación de metabolitos en la lámina foliar de Sechium edule (Jacq.) Sw.

Table 1. Sites of synthesis and accumulation of metabolites in the leaf of Sechium edule (Jacq.) Sw.

\section{Discussion}

Studies on the Cucurbitaceae species have shown that the shape of the petiole is quite variable. In Momordica tuberosa Cogn., Kumar et al. (2010), a convex outline on the adaxial face and a triangular outline on the abaxial face were observed. In Momordica charantia L., Sá et al. (2018) a convex outline with two proeminences on the adaxial face and a triangular outline on the abaxial face were observed. Vieira et al. (2019b) observed that the petiole of Luffa cylindrica (L.) M. Roem has a rounded outline, with two proeminences on the adaxial face. Another characteristic of the petiole that has also shown to be variable and important for distinguishing Cucurbitaceae species is the number of vascular bundles (Sãvulescu \& Hoza 2010, Aguoru \& Okoli 2012, Rus et al. 2015, Sá et al. 2018, Vieira et al. 2019b).

In the leaf blade of Cucurbitaceae species, in addition to the variable number of vascular bund- les (Ajuru \& Okoli 2013, Mohammed \& Guma 2015), the type of bundle may also vary. The most common type of vascular in the species of the family is the bicollateral one (Metcalfe \& Chalk 1950). However, collateral vascular bundles have already been reported, for example in the leaves of M. charantia (Coutinho et al. 2010), Bryonia alba L. (Rus et al. 2015) and L. cylindrica (Vieira et al. 2019b).

The presence of glandular and non-glandular trichomes is another common characteristic in the Cucurbitaceae family (Inamdar et al. 2019). Ali \& Al-Hemaid (2011) cited the presence of conical trichomes in $S$. edule. Cadena-Iñiguez (2005) found five types of trichomes in eight varieties of $S$. edule, collected in Mexico, for which they studies the leaf anatomy.

Most Cucurbitaceae stomata are anomocytic, but other types are also found, such as paracytic, tetracytic, staurocytic, anysocytic, cyclocytic or occasionally have only a single subsidiary cell. Cadena-Iñiguez (2005) observed stomata only on the abaxial face of $S$. edule, while our study corroborates the data described by Inamdar et al. (2019) describing the leaf lamina of the species as amphiestomatic.

Regarding the metabolites searched through histochemistry, the results are in agreement with the literature data that report that triterpenes and steroids are common in the Cucurbitaceae family (Valente 2004). Cucurbitacins, for example, are triterpenes found in members of Cucurbitaceae and also in other plant families and have an important pharmacological potential, being responsible for anti-inflammatory, antitumor, antidiabetic responses, among others activities (Kaushik et al. 2015). They are usually present in plants as $\beta$-glucosides and the most commonly found in the plant kingdom are cucurbitacins B and D (Cadena-Iñiguez et al. 2007).

Alkaloids have been identified in $S$. edule fruits (Salama et al. 1986, Sibi et al. 2013). In the leaves, Noumedem et al. (2013) identified alkaloids present in their methanolic extract, which exhibited activity against Gram-negative multidrug-resistant bacteria. Regarding the phenolic compounds, there was divergence with the literature data. The present study did not detected their presence, while other studies on the leaf of this species identified these metabolites, correlating them with the antioxidant activity (Ordonez et al. 2006, Ibarra-Alvarado et al. 2010, Chao et al. 
2014). Among the flavonoids, Chao et al. (2014) identified in $S$. edule quercetin, myricetin, morin and kaempferol, myricetin being found in the highest concentrations. Taking into account that in the literature studies that identified flavonoids the species was collected in different locations, the difference with the present result can be explained by the fact that secondary metabolites represent a chemical interconnection between the plants and the environment to which they are inserted. Therefore, their synthesis is often affected by environmental conditions (Gobbo-Neto \& Lopes 2007).

In the studies of Sá et al. (2018) and Vieira et al. (2019b), histochemical tests for tannins were also negative. At the same time, Vieira et al. (2019b) did not identify starch in L. cylindrica leaf blade, while Sá et al. (2018) observed starch in the midrib parenchyma of $M$. charantia.

The study brought new information about the location of metabolites in the leaf blade of $S$. edule, as well as demonstrated the useful characters in the identification of the species, which constitutes a great contribution to the taxonomy of the Cucurbitaceae family. The information gathered here also have great importance to assist in the pharmacobotanical standardization of $S$. edule, given its broad medicinal use and the evidence of its therapeutic potential reported in the literature.

\section{References}

Agra MF, Silva KN, Basílio IJLD, Freitas PF \& BarbosaFilho JM. 2008. Survey of medicinal plants used in the region Northeast of Brazil. Revista Brasileira de Farmacognosia 18(3): 472-508. https://doi.org/10. 1590/S0102-695X2008000300023

Aguoru CU \& Okoli BE. 2012. Comparative stem and petiole anatomy of West African species of Momordica L (Cucurbitaceae). African Journal of Plant Science 6(15): 403-409. https://doi.org/10.5897/AJ PS11.309

Ajuru MG \& Okoli BE. 2013. Comparative vegetative anatomy of some species of the Family Cucurbitaceae Juss in Nigeria. Research Journal of Botany 8(1): 15-23. https://doi.org/10.3923/rib.2013.15. $\underline{23}$

Ajuru M\& Nmom F. 2017. A review on the economic uses of species of Cucurbitaceae and their sustainability in Nigeria. American Journal Plant Biology 2(1): 17-24.

Ali MA \& Al-Hemaid FMA. 2011. Taxonomic significance of trichomes micromorphology in cucurbits. Saudi Journal of Biological Sciences 18(1): 87-92. https:// doi.org/10.1016/j.sjbs.2010.10.003

Bukatsch F. 1972. Bemerkungen zur doppelfärbung Astrablau-Safranin. Mikrokosmos 61 (8): 255.
Cadena-Iñiguez J. 2005. Caracterización morfoestructural, fisilógica, química y genética de diferentes tipos de chayote (Sechium edule (Jacq.) Sw.). Texcoco, México: Colegio de Postgraduados. Tesis Doctoral.

Cadena-Iñiguez J, Arévalo-Galarza L, Avendaño-Arrazate $\mathrm{CH}$, Soto-Hernández $\mathrm{M}$, Ruiz-Posadas $\mathrm{LM}$, Santiago-Osorio E, . . . Ochoa-Martínez D. 2007. Production, genetics, postharvest management and pharmacological characteristics of Sechium edule (Jacq.) Sw. Fresh Produce 1(1): 41-53.

Chao PY, Lin SY, Lin KH, Liu YF, Hsu JI, Yang CM \& Lai JY. 2014. Antioxidant Activity in Extracts of 27 Indigenous Taiwanese Vegetables. Nutrients 6(5): 21152130. https://doi.org/10.3390/nu6052115

Christenhusz MJM \& Byng JW. 2016. The number of known plants species in the world and its annual increase. Phytotaxa 261(3): 201-217. http://dx.doi.org/ 10.11646/phytotaxa.261.3.1

Coutinho DF, Florêncio JC, Aguiar LR, Rodrigues KAF, Vilanova CM \& Borba ERC. 2010. Estudo farmacobotânico das folhas de Momordica charantia L. (Cucurbitaceae). Visão Acadêmica 10(1): 7-17. http://dx. doi.org/10.5380/acd.v10i1.21314

Gobbo-Neto L \& Lopes NP. 2007. Plantas medicinais: fatores de influência no conteúdo de metabólitos secundários. Química Nova 30(2): 374 https://doi. org/10.1590/S0100-40422007000200026

Gomes-Klein VL, Lima LFP, Gomes-Costa GA \& Medeiros ES. 2015. Cucurbitaceae in Lista de Espécies da Flora do Brasil. Jardim Botânico do Rio de Janeiro. Available at http://floradobrasil.jbri.gov.br/ jabot/floradobrasil/FB17036. (accessed on 02-IV2020).

Ibarra-Alvarado C, Rojas A, Mendoza S, Bah M, Gutiérrez DM, Hernández-Sandoval L \& Martínez M. 2010. Vasoactive and antioxidant activities of plants used in Mexican traditional medicine for the treatment of cardiovascular diseases. Pharmaceutical Biology 48(7): 732-739 https://doi.org/10.3109/1388020090 $\underline{3271280}$

Inamdar JA, Gangadhara M\& Shenoy KN. 2019. Structure, ontogeny, organographic distribution, and taxonomic significance of trichomes and stomata in the Cucurbitaceae. In: Robinson BMDRW \& Jeffrey C (editor). Biology and Utilization of the Cucurbitaceae.Cornell University Press.

Johansen DA. 1940. Plant microtechnique. New York: McGraw-Hill Book Company Inc.

Kaushik U, Aeri V\& Mir SR. 2015. Cucurbitacins-an insight into medicinal leads from nature. Pharmacognosy Reviews 9 (17): 12. https://doi.org/10.410 3/0973-7847.156314

Kraus JE \& Arduin M. 1997. Manual básico de métodos em morfologia vegetal. Rio de Janeiro: EDUR.

Krauter D. 1985. Erfahrungen mit Etzolds FSA-Färbung für pflanzenschnitte. Mikrokosmos 74: 231-233.

Kumar P, Rao D, Bilakanti L \& Setty R. 2010. Pharmacognostical studies on Momordica tuberosa Cogn. Pharmacognosy Journal 2(5): 28-33.

Mace ME, Bell AA \& Stipanovic RD. 1974. Histochemistry and isolation of gossypol and related terpenoids in root of cotton seedlings. Phytopathology 64(10): 
1297-1302. https://doi.org/10.1094/Phyto-64-1297

Mace ME \& Howeel CR. 1974. Histochemistry and identification of condensed tannin precursor in roots of cotton seedling. Canadian Journal of Botany 52(11): 2423-2426. https://doi.org/10.1139/b74-314

Madison D. 2017. The Illustrated Encyclopedia of Fruits, Vegetables, and Herbs: History, Botany, Cuisine. New York: Chartwell Books.

Medeiros MFT, Fonseca VS \& Andreata RHP. 2014. Plantas medicinais e seus usos pelos sitiantes da Reserva Rio das Pedras, Mangaratiba, RJ, Brasil. Acta Botanica Brasilica 18(2):391-399. https://doi. org/10.1590/S0102-33062004000200019

Messias MCTB, Menegatto MF, Prado ACC, Santos BR \& Guimarães MFM. 2015. Uso popular de plantas medicinais e perfil socioeconômico dos usuários: um estudo em área urbana em Ouro Preto, MG, Brasil. Revista Brasileira de Plantas Medicinais 17(1): 76104. https://doi.org/10.1590/1983-084X/12 139

Metcalfe CR \& Chalk L. 1950. Anatomy of the dicotyledons. Oxford: Claredon Press.

Mishra LK \& Das P. 2015. Nutritional evaluation of squash (Sechium edule) germplasms collected from garo hills of meghalaya-north East India. International Journal of Agriculture Environment and Biotechnology 8(4): 971. https://doi.org/10.5958/2230732X.2015.00111.4

Mohammed IA \& Guma AGN. 2015. Anatomical diversity among certain genera of family Cucurbitaceae. International Journal of Research Studies in Biosciences 3: 85-91.

Noumedem JAK, Mihasan M, Lacmata ST, Stefan M, Kuiate JR \& Kuete V. 2013. Antibacterial activities of the methanol extracts of ten Cameroonian vegetables against Gram-negative multidrug-resistant bacteria. BMC Complementary and Alternative Medicine 13(26): 1-9. http://www.biomedcentral.com/147 2-6882/13/26

Nunes MG, Bernardino AO \& Martins RD. 2015. Uso de plantas medicinais por pessoas com hipertensão. Revista Rene 16(6): 775-781. https://doi.org/10.15 253/2175-6783.2015000600002

Oliveira FCS, Barros RFM \& Moita Neto JM. 2010. Plantas medicinais utilizadas em comunidades rurais de Oeiras, semiárido piauiense. Revista Brasileira de Plantas Medicinais 12(3): 282-301. https://doi.org/10.1590/S1516-05722010000300006

Ordoñez AAL, Gomez JD, Vattuone MA \& Isla MI. 2006. Antioxidant activities of Sechium edule (Jacq.) Swartz extracts. Food Chemistry 97(3): 452-458. https://doi.org/10.1016/j.foodchem.2005.05.024

Pereira LP, Fernandes JM \& Leite JPV. 2012. Ethnopharmacological survey: a selection strategy to identify medicinal plants for a local phytotherapy program. Brazilian Journal of Pharmaceutical Sciences 48(2): 299-313. https://doi.org/10.1590/S1984-8250 2012000200014

Rajasree RS, Sibi PI, Francis F \& William H. 2016. Phytochemicals of Cucurbitaceae family - A review. International Journal of Pharmacognosy and Phytochemical Research 8(1): 113-123.

Rodrigues AP \& Andrade LHC. 2014. Levantamento etnobotânico das plantas medicinais utilizadas pela comunidade de Inhamã, Pernambuco, Nordeste do Brasil. Revista Brasileira de Plantas Medicinais 16(3): 721-730. https://doi.org/10.1590/1983-084x/ 08_159

Rus L, lelciu II, Paltinean R, Vlase L, Stefanescu C \& Crisan G. 2015. Morphological and histo-anatomical study of Bryonia alba L. (Cucurbitaceae). Notulae Botanicae Horti Agrobotanici Cluj-Napoca 43(1): 4752. https://doi.org/10.15835/nbha4319713

Sá RD, Cadena MB, Padilha RJR, Alves LC \& Randau KP. 2018. Anatomical Study andCharacterization of Metabolites in Leaves of Momordica charantia L. Pharmacognosy Journal 10(5): 823-826 https://doi. org/10.5530/pj.2018.5.140

Saade RL. 1996. Chayote. Sechium edule (Jacq.)Sw. Promoting the conservation and use of underutilized and neglected crops. 8. Rome, Italy: Institute of Plant Genetics and Crop Plant Research, Gatersleben/International Plant Genetic Resources Institute.

Salama AM, Polo AE, Contreras CR \& Maldonado L. 1986. Análisis fitoquímico preliminar y determinación de las actividades antiinflamatoria y cardíaca de los frutos de Sechium edule. Revista Colombiana de Ciencias Químico-Farmacéutica 15(1): 79-82.

Santos MM, Nunes MGS \& Martins RD. 2012. Uso empírico de plantas medicinais para tratamento de diabetes. Revista Brasileira de Plantas Medicinais 14(2): 327-334. https://doi.org/10.1590/S1516-0572 $\underline{2012000200012}$

Sass JE. 1951. Botanical microtechnique. Ames: The lowa State College Press.

Sãvulescu E \& Hoza G. 2010. Research results regarding the anatomy of Momordica charanthia L. specie. Lucrări ştiințifice USAMVB, Seria B, Horticultură 54 : 694-700.

Sibi G, Kaushik K, Dhananjaya K, Ravikumar K \& Mallesha H. 2013. Antibacterial activity of Sechium edule (Jacq.) Swartz against Gram negative food borne bacteria. Advances in Applied Science Research 4(2): 259-261.

Souza LF, Dias RF, Guilherme FAG \& Coelho CP. 2016. Plantas medicinais referenciadas por raizeiros no município de Jataí, estado de Goiás. Revista Brasileira de Plantas Medicinais 18(2): 451-461. https://doi.org/10.1590/1983-084X/15_173

Valente LMM. 2004. Cucurbitacinas e suas principais características estruturais. Química Nova 27(6): 944-948. https://doi.org/10.1590/S0100-404220040 $\underline{00600019}$

Vendruscolo GS \& Mentz LA. 2006. Estudo da concordância das citações de uso e importância das espécies e famílias utilizadas como medicinais pela comunidade do bairro Ponta Grossa, Porto Alegre, RS, Brasil. Acta Botanica Brasilica 20(2): 367-382. https://doi.org/10.1590/S0102-33062006000200012

Vieira EF, Pinho O, Ferreira IMPLVO \& Delerue-Matos C. 2019. Chayote (Sechium edule): A review of nutritional composition, bioactivities and potential applications. Food Chemistry 275: 557-568. https://doi.org/ 10.1016/j.foodchem.2018.09.146

Vieira LEB, Sá RD \& Randau KP. 2019. Anatomical and 
Histochemical Characterization of Leaves of Luffa cylindrica (L.) M. Roem. Pharmacognosy Journal 11(3): 511-514. https://doi.org/10.5530/pj.2019.11.81 Yoder LR \& Mahlberg PG. 1976. Reactions of alkaloid and histochemical indicators in laticifers and specialized parenchyma cells of Catharanthus roseus (Apocynaceae). American Journal of Botany 63: 11671173. https://doi.org/10.2307/2441734 